\title{
Beneficial effects of bio-controlling agent Bacillus cereus IB311 on the agricultural crop production and its biomass optimization through response surface methodology
}

\author{
GOUTAM BANERJEE ${ }^{1}$, SRIKANTH GORTHI ${ }^{2}$ and PRITAM CHATTOPADHYAY ${ }^{3}$ \\ ${ }^{1}$ Department of Biochemistry, University of Calcutta, PIN-700019, West Bengal, India \\ ${ }^{2} \mathrm{M} / \mathrm{S}$ Ajay Biotech India Ltd., Pune, 411 003, Maharastra, India \\ ${ }^{3}$ Department of Biotechnology, Gauhati University, Guwahati, 781014, Assam, India
}

Manuscript received on May 15, 2017; accepted for publication on July 12, 2017

\begin{abstract}
Disease in agricultural field is a big problem that causes a massive loss in production. In this present investigation, we have reported a soil-borne bacterium Bacillus cereus IB311 which is antagonistic to plant pathogens (Pseudomonas syringae and Agrobacterium tumefaciens), and could make a substantial contribution to the prevention of plant diseases. To prove the practical application, the strain was directly applied in agricultural field. The results demonstrated that B. cereus IB311 has increased the production ( $20 \%$ and $26 \%$ in term of average pod number per plant, average seed number per pod, and seed yield per experimental plot) in ground nut (Arachis hypogaea var. Koushal, G201) and sesame (Sesamum indicum var. Kanak), respectively. To reduce the production cost, the biomass production was optimized through response surface methodology (RSM). Interactions of three variables (glucose, beef extract and inoculum) were studied using Central Composite Design. According to our analysis, optimum production of Bacillus cereus IB311 $(5.383 \mu \mathrm{g} / \mathrm{mL})$ may be obtained at glucose $1.985 \%$, beef extract $1.615 \%$ and inoculums size $0.757 \%$. Therefore, we strongly believe that the application of this strain in agricultural field as biocontrolling agent will definitely enhance the production yield and will reduce the disease risk.
\end{abstract}

Key words: Bacillus cereus, bio-control, phytopathogens, RSM, field application, crop production.

\section{INTRODUCTION}

Plants harbor a wide range of bacteria, which may be beneficial or pathogenic. The types of interactions include mutualism, proto-cooperation, commensalism, neutralism, competition, amensalism, parasitism and predation (Bull and Koike 2015). Plant disease is an impairment of the

Correspondence to: Pritam Chattopadhyay

E-mail: pritam.biotechnol@gmail.com

* Contribution to the centenary of the Brazilian Academy of Sciences. normal state of a plant that interrupts or modifies its vital functions. Till date, many plant bacterial phytopathogens have been identified such as Agrobacterium tumefaciens, Dickeya (dadantii and solani), Erwinia amylovora, Pectobacterium carotovorum, Pseudomonas syringae, Ralstonia solanacearum, Xanthomonas oryzae, Xanthomonas campestris, Xanthomonas axonopodis and Xylella fastidiosa. Virtually, all species of plants are subject to bacterial disease. The occurrence and prevalence of bacterial plant diseases vary time to time, depending on the presence of the 
pathogen, environmental conditions, and the crops and varieties grown (Mansfield et al. 2012). The organism that suppresses the pest or pathogen is referred to as the biological control agents (BCA). According to the members of the U.S. National Research Council, 'Biological control is the use of natural or modified organisms, gene, or gene products, to reduce the effect of undesirable organisms and to favor desirable organisms such as crops, beneficial insects, and microorganisms' (O’Neil 1997). These bio-control candidates represent an eco-friendly alternative to the use of chemical pesticides in agriculture. Microbes that contribute to disease control are most likely those that could be classified competitive saprophytes, facultative plant symbionts, and facultative hyperparsites.

Among the 20 genera of bacteria, Bacillus spp., Pseudomonas spp., and Streptomyces spp. are widely used as bio-control agents (Islam et al. 2012). There is a huge demand of chemical residue free crops in both domestic and international market. Therefore, soil-borne bacteria that are antagonistic to plant pathogens could make a substantial contribution in preventing plant diseases. Rhizospheric soil has conventionally been used as a model environment for screening of putative agents for the biological control of soil-borne plant pathogens (Majeed et al. 2015). Therefore, the objectives of this present investigation were to (i) isolate bacterial strains from soils of anjeer orchard (ii) characterize and identify the most potential anti-phytopathogenic candidate (iii) practical application of this biocontrolling agent in agricultural field and (iv) optimize environmental and nutritional condition for maximum production of this bio-controlling agent through Response Surface Methodology (RSM).

\section{MATERIALS AND METHODS}

\section{CULTURE MEDIUM}

Two plant pathogenic bacteria viz. Agrobacterium tumefaciens MTCC No. 609 and Pseudomonas syringae MTCC No. 1604 were grown in Tryptone Yeast Extract Broth (YEB, HiMedia, India) and Cetrimide Broth (CB, HiMedia, India) medium, respectively.

\section{ISOLATION OF BACTERIA FROM SOIL}

Soil samples were collected from agricultural field of the village Khalad, Purandar, Pune district of Maharashtra, India following the methods of Krieg (1987). The field had no history of application of pesticides and fertilizer, at least six months prior to the collection. One gram of soil was dissolved in $10 \mathrm{~mL}$ of sterile double distilled water and serial dilution was done accordingly. $100 \mu \mathrm{L}$ sample from each dilution was taken and plated in NA medium plates ( $\mathrm{pH}$ 7.2), followed by $24 \mathrm{~h}$ incubation period at $30{ }^{\circ} \mathrm{C}$. Colonies were selected on the basis of distinctive morphology. Pure cultures were obtained through repeated streaking method. The cultures were stored at $4^{\circ} \mathrm{C}$ for further use.

\section{SCREENING OF SOIL ISOLATES FOR PLANT PATHOGEN ANTAGONISM}

A total of 36 bacterial strains were tested for antimicrobial activity. A loop full pure culture was inoculated in $200 \mathrm{~mL}$ of LB media and the supernatant was collected by centrifugation $\left(10,000 \times \mathrm{g}, 4^{\circ} \mathrm{C}\right)$. Solvent extraction was done by adding ethyl acetate to the supernatants and the mixture was agitated for $45 \mathrm{~min}$. Solvent phase was then separated, collected and dried by solvent evaporation. The crude powder was weighed and then resuspended in DMSO, sterilized using syringe filters and stored at $4^{\circ} \mathrm{C}$. The crude powders after dissolving in DMSO were tested for antibacterial activity against test organisms (phytopathogens) following the standard disc diffusion method (Serrano et al. 2004). The Minimum Inhibitory 
Concentration (MIC) and the Minimum Bacterial Concentration (MBC) were determined using brothdilution method (Tyler et al. 1988). The number of bacteria killed in the MIC was determined by serial dilution technique.

\section{CHARACTERIZATION OF THE SCREENED ISOLATES}

The most promising strain was selected and subjected to morphological characterization. Single colony of the isolate was subjected to Gram staining, endospore staining and motility analysis. The results were observed by light microscopy under suitable magnification. Carbohydrate fermentation tests (CFT) were studied using HiCarbo KB009KT kit (HiMedia, India) containing a set of 35 carbohydrates (Table I).

16S RDNA SEQUENCE AND PHYLOGENY ANALYSIS
Bacterial genomic DNA was isolated using gene O-spin microbial DNA isolation kit. Bacterial 16S gene region was amplified using standard $\mathrm{PCR}$ reaction and the products were checked on $1 \%$ agarose by agarose gel electrophoresis, and the amplicon size was compared using reference ladder. The PCR products were then purified using Gene O-spin PCR product purification kit and were directly sequenced using an ABI PRISM Big Dye Terminator V 3.1 kit (Applied Biosystems, USA). The sequences were analyzed using Sequencing Analysis 5.2 software. BLAST analysis was performed at BlastN site at NCBI server (http:// www.ncbi.nlm.nih.gov/blast). Multiple sequence alignments were done using CLUSTAL $\mathrm{W}$ and the phylogenetic tree was constructed using neighborjoining algorithm. For statistical validation of the tree, boot-strap (10,000 replicates) method was used. All the phylogenetic analysis was carried out

TABLE I

Morphological and biochemical characterization of the isolate IB131.

\begin{tabular}{lc}
\hline Isolate IB131 & Results \\
\hline Morphological parameter & $4 \mathrm{~mm}$ \\
\hline Size & Filamentous \\
Shape & Entire \\
Margin & Creamy \\
Colour & Transluscent \\
Opacity & Flat \\
Elevation & Butyrous \\
Consistency & Present (subterminal) \\
Sporulation & - \\
Motility & + \\
Gram stain & \\
\hline Biochemical parameter & \\
(HiCarbo KB009-KT Kit) & \\
\hline Lactose, Xylose, Fructose, Galactose, Raffinos, Trehalose, Sucrose, \\
$\begin{array}{l}\text { L-arabinose, Mannose, Inulin, Sodium gluconate, Salicin, Dulcitol, } \\
\text { ONPG, Inositol, Sorbitol, Mannitol, Mannitol, Adonitol, Arabitol, } \\
\text { Erythritol, } \alpha \text {-methyl-D-glucoside, Rhamnose, Cellobiose, Melezitose, } \\
\alpha \text {-methyl-D-mannoside, Xylitol, Esculin hydrolysis, D-arabinose, Sorbose }\end{array}$ \\
\hline $\begin{array}{l}\text { Maltose, Dextrose, Melibiose, Glycerol, Citrate utilization, Malonate } \\
\text { utilization }\end{array}$ & - \\
\hline+ : positive test result; - : negative test result. & \\
\hline
\end{tabular}


using MEGA6 (Tamura et al. 2013).

APPLICATION OF BIO-CONTROLLING AGENT IN AGRICULTURAL FIELD

The selected bacterial strain was inoculated in 200 $\mathrm{mL}$ of LB media (pH 7.0) and incubated for 5 days at $37^{\circ} \mathrm{C}, 110 \mathrm{rpm}$. The broth was then centrifuged at $10,000 \times \mathrm{g}, 20 \mathrm{~min}, 4^{\circ} \mathrm{C}$. The cell pallet was collected and the cfu was adjusted to $1.5 \times 10^{10}$ $\mathrm{cfu} / \mathrm{mL}$. Field trials were conducted in Ravi season in experimental field. Soil type was red laterite. The field was kept idle for 6 months prior to seed sowing for avoiding effects of any pesticide. Plots of $3.5 \mathrm{~m} \times 4.0 \mathrm{~m}$ were laid out and brought to a fine tilt by ploughing. Soils of the plots were mixed well ensuring leveling and rows were made in $30 \mathrm{~cm}$ apart. Randomized complete block design (RBCD) model was followed for the experiments. Untreated (TS1) experimental plots were taken as control, whereas other plots supplied with $100 \%$ recommended dose of NPK (60:60:50) (TS2) were also maintained as positive control. Plots treated with experimental strain (TS3), $90 \mathrm{ml} 1.5 \times 10^{10}$ $\mathrm{cfu} / \mathrm{mL}$ mixed with $5 \mathrm{Kg}$ of double autoclaved powdered soil to broadcast over one plot area $(3.5 \mathrm{~m}$ $\times 4.0 \mathrm{~m}$ ). All the experimental plots were irrigated, as required to maintain the moisture level at $15 \%$. In each case, treatment was carried out one hour before sunset (Chattopadhyay et al. 2014). After preparation of the field, surface sterilized seeds of ground nut (Arachis hypogaea var. Koushal, G201) and sesame (Sesamum indicum var. Kanak) were showed. Row to row distance was maintained at 30 $\mathrm{cm}$, whereas, plant to plant distance was maintained $20 \mathrm{~cm}$.

In order to analyze the productivity, yield parameters (average pod number per plant, PN; average seed number per pod, SN; seed yield per experimental plot, SY) were measured. The experimental results were statistically analyzed using ANOVA. Duncan's multiple range test (DMRT) was used to determine group mean value, when ANOVA was found significant at $\mathrm{P}<0.05$ (Chattopadhyay et al. 2014).

\section{OPTIMIZATION OF BIOMASS PRODUCTION BY RESPONSE SURFACE METHODOLOGY}

Three variables (glucose, beef extract and inoculam size) central composite design (CCD) for response surface methodology was carried out to optimize the production of the selected isolate. Statistical analysis was done using 'DESIGN-EXPERT ${ }^{\circledR}$ 10.0.3'software package. Level of different factors was taken as $-1,0$, and +1 (Table II). Twenty experiments were conducted to maximize the effect of unexplained variability using biomass dry weight as response. Relationship between coded value and actual value in this experiment was given in Equation 1.

$\mathrm{Xi}=\mathrm{xi}-\mathrm{x} 0 / \Delta \mathrm{x} ; \mathrm{i}=1,2,3$

Where, $x_{i}$ denotes coded value, $x_{0}$ denotes actual value, and $\Delta \mathrm{x}$ denotes step change of $\mathrm{x}_{\mathrm{i}}$. Optimum conditions for production were predicted from a second order polynomial model as described below in Equation 2.

$\mathrm{Y}=\mathrm{b} 0+\mathrm{b} 1 \mathrm{X} 1+\mathrm{b} 2 \mathrm{X} 2+\mathrm{b} 3 \mathrm{X} 3+\mathrm{b} 12 \mathrm{X} 1 \mathrm{X} 2+\mathrm{b} 13 \mathrm{X} 1 \mathrm{X} 3+$ b23X2X3+b11X12+b22X22+b33X32

where $\mathrm{Y}$ denotes response, $\mathrm{b}_{0}$ denotes model constant $X_{1}, X_{2}$, and $X_{3}$ were the variable $b_{1}, b_{2}$, and $b_{3}$ are linear interaction $b_{12}, b_{13}$, and $b_{23}$ are cross product interaction, $\mathrm{b}_{11}, \mathrm{~b}_{22}$, and $\mathrm{b}_{33}$ are quadratic interaction.

\section{RESULTS AND DISCUSSION}

\section{ISOLATION, SCREENING AND SELECTION}

The strain IB131 has been identified as the most promising bio-controlling candidate against the bacterial phytopathogens on the basis of the inhibition zone (Table III). The highest zone of inhibition was recorded against $P$. syringae (21 
TABLE II

Central Composite Design showing production of Bacillus cereus strain IB311 at different variable combinations.

\begin{tabular}{|c|c|c|c|c|c|c|c|}
\hline \multirow[b]{2}{*}{ Run } & \multicolumn{3}{|c|}{ Coded value } & \multicolumn{4}{|c|}{ Actual value } \\
\hline & $\begin{array}{c}\text { Glucose } \\
\text { (A) }\end{array}$ & $\begin{array}{c}\text { Beef extract } \\
\text { (B) }\end{array}$ & $\begin{array}{l}\text { Inoculum size } \\
\text { (C) }\end{array}$ & $\begin{array}{c}\text { Glucose }(\%) \\
\text { (A) }\end{array}$ & $\begin{array}{c}\text { Beef extract } \\
(\%) \\
\text { (B) }\end{array}$ & $\begin{array}{l}\text { Inoculum size } \\
\qquad \begin{array}{c}(\%) \\
(\mathrm{C})\end{array}\end{array}$ & $\begin{array}{c}\text { Biomass } \\
\mathrm{mg} / \mathrm{mL}\end{array}$ \\
\hline 1 & -1 & -1 & -1 & 2 & 0.5 & 1 & 3.8 \\
\hline 2 & +1 & -1 & -1 & 6 & 0.5 & 1 & 4 \\
\hline 3 & -1 & +1 & -1 & 2 & 2 & 1 & 5.6 \\
\hline 4 & +1 & +1 & -1 & 6 & 2 & 1 & 5.7 \\
\hline 5 & -1 & -1 & +1 & 2 & 0.5 & 2 & 3 \\
\hline 6 & +1 & -1 & +1 & 6 & 0.5 & 2 & 4.5 \\
\hline 7 & -1 & +1 & +1 & 2 & 2 & 2 & 5.3 \\
\hline 8 & +1 & +1 & +1 & 0.5 & 2 & 2 & 5.3 \\
\hline 9 & $-\alpha$ & 0 & 0 & 7.5 & 1.25 & 1.5 & 4.3 \\
\hline 10 & $+\alpha$ & 0 & 0 & 4 & 1.25 & 1.5 & 4.9 \\
\hline 11 & 0 & $-\alpha$ & 0 & 4 & 0.1 & 1.5 & 2.4 \\
\hline 12 & 0 & $+\alpha$ & 0 & 4 & 2.4 & 1.5 & 5.4 \\
\hline 13 & 0 & 0 & $-\alpha$ & 4 & 1.25 & 0.25 & 4.5 \\
\hline 14 & 0 & 0 & $+\alpha$ & 4 & 1.25 & 2.75 & 4.9 \\
\hline 15 & 0 & 0 & 0 & 4 & 1.25 & 1.5 & 5 \\
\hline 16 & 0 & 0 & 0 & 4 & 1.25 & 1.5 & 4.8 \\
\hline 17 & 0 & 0 & 0 & 4 & 1.25 & 1.5 & 4.8 \\
\hline 18 & 0 & 0 & 0 & 4 & 1.25 & 1.5 & 5 \\
\hline 19 & 0 & 0 & 0 & 4 & 1.25 & 1.5 & 5.3 \\
\hline 20 & 0 & 0 & 0 & 4 & 1.25 & 1.5 & 5.1 \\
\hline
\end{tabular}

TABLE III

Antiphytopathogenic activity of the isolate IB131.

\begin{tabular}{ccccc}
\hline $\begin{array}{c}\text { Name of the phytopathogenic } \\
\text { bacteria }\end{array}$ & $\begin{array}{c}\text { Zone of inhibition } \\
(\mathrm{mm} @ 30 \mu \mathrm{g} / \mathrm{mL})\end{array}$ & $\begin{array}{c}\text { Approximate count } \\
\text { in } 60 \mu \mathrm{L} \text { at } 12 \mathrm{~h} \\
\text { fresh culture }(\mathrm{cfu})\end{array}$ & $\begin{array}{c}\text { MIC } \\
(\mu \mathrm{g} / \mathrm{mL})\end{array}$ & $\begin{array}{c}\mathrm{MBC} \\
(\mu \mathrm{g} / \mathrm{mL})\end{array}$ \\
$\begin{array}{c}\text { A. tumefaciens MTCC } 609 \\
\text { P. syringae MTCC 1604 }\end{array}$ & 9 & $0.11 \times 10^{6}$ & 8 & 2 \\
\hline
\end{tabular}

$\mathrm{mm})$, followed by $A$. tumefaciens $(9 \mathrm{~mm})$. The MIC value of the crude powder was determined to be 8 and $2 \mu \mathrm{g} / \mathrm{mL}$, respectively (Table III). The number of phytopathogenic bacteria inhibited by the MIC was also determined. The number of pathogenic bacteria in $60 \mu \mathrm{L}$ of broth were measured to be $0.11 \times 10^{6}$ (A. tumefaciens) and $0.42 \times 10^{6}(P$. syringae) cfu (Table III). Furthermore, the MBC value of the crude powder against $A$. tumefaciens and $P$. syringae were obtained to be 16 and $2 \mu \mathrm{g} /$ $\mathrm{mL}$, respectively (Table III).

The bacterial species; A. tumefaciens and $P$. syringae are considered to be potential phytopathogen based on their scientific and economic importance in plant diseases (Mansfied et al. 2012). Members of the species A. tumefaciens 
are plant pathogens that cause tumors mostly at the crown of dicotyledonous plant species (Subramoni et al. 2015). The diversification of lineages within $P$. syringae has involved a number of adaptive shifts from herbaceous host onto various species of tree, resulting in the emergence of highly destructive diseases such as bacterial cancer of kiwi and bleeding cancer of horse chestnut (Nowell et al. 2016). Our results clearly indicated the inhibition potentiality of the isolate IB131 against phytopathogen, as a minimum concentration of crude powder $(2 \mu \mathrm{g} / \mathrm{mL})$ inhibited about $0.42 \times 10^{6}$ cfu of $P$. syringae. Furthermore, the higher value of $\mathrm{MBC}$ compared to MIC inferred that the nature of the crude powder was bacteriostatic rather than bacteriocidal.

\section{CHARACTERIZATION AND IDENTIFICATION OF THE STRAIN IB131}

The strain IB131 was found to be Grampositive, rod-shaped, aerobic bacteria (Table I). The candidate strain IB131 (Table I) actively utilized glucose, reduced nitrogen, and synthesized catalase enzyme, but unable to utilize mannitol, and was therefore predicted to be a strain of Bacillus (Wong et al. 1988). 16S ribosomal RNA gene sequence spanning 1183 bp was submitted to NCBI GenBank (accession no. KX685929). The phylogenetic

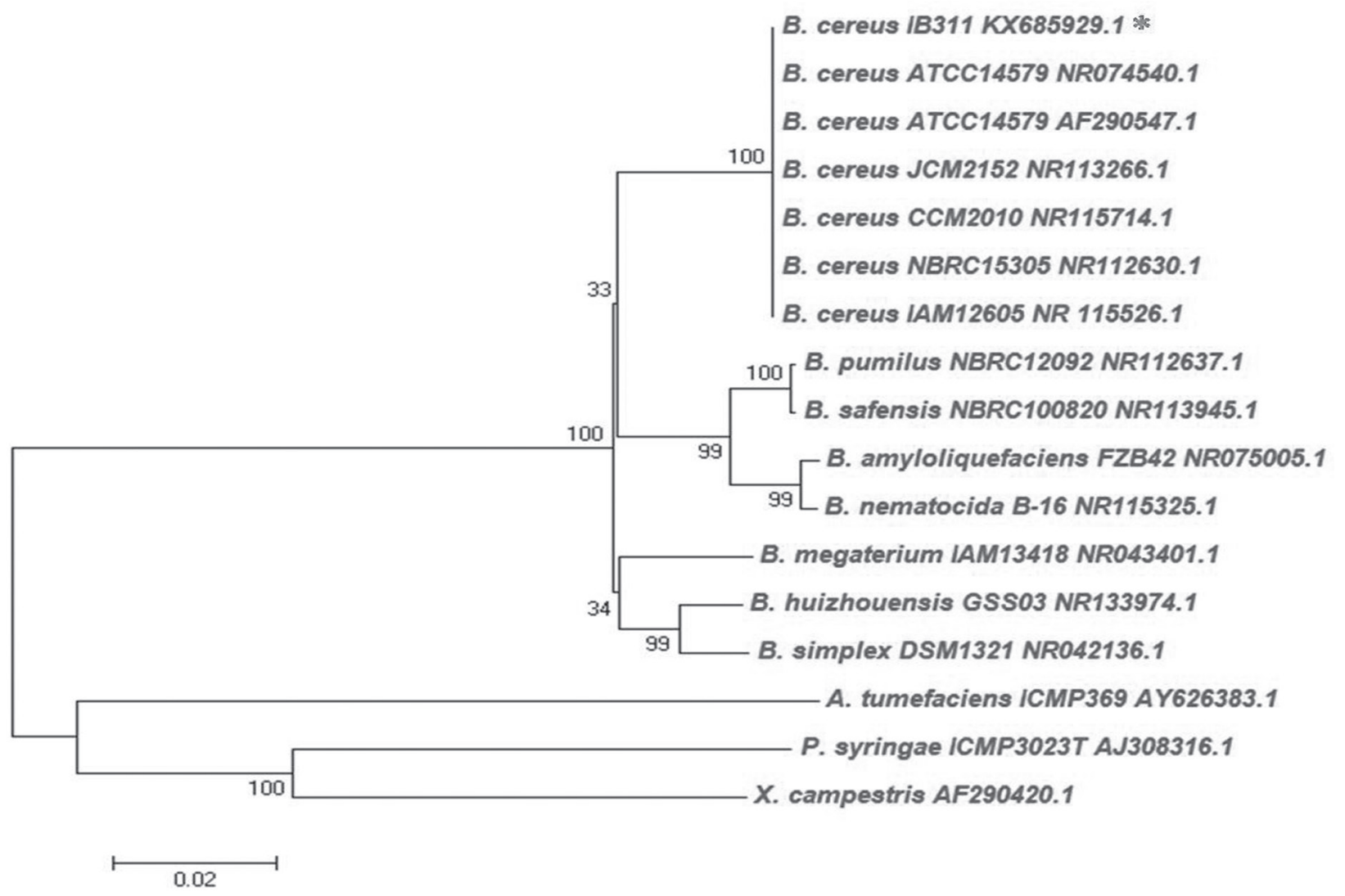

Figure 1 - Neighbour-joining tree based on partial 16S rRNA gene sequences showing relationships of Bacillus cereus strain IB311 (denoted with asterisks) with other close homologous strains. Three phytopathogenic bacteria (viz., Agrobacterium tumefaciens, Pseudomons syringae and Xanthomonas campestris) were used as outgroups. Bootstrap values greater than 50\% are highlighted at the nodes (100 replications). The scale bar represents 2 substitutions per 100 bases. Evolutionary analyses were conducted in MEGA 6.06. 
relationship of the isolate IB131 exhibited 100\% homology to B. cereus ATCC 14579, B. cereus JCM 2152 and B. cereus NBRC 15305 (Fig. 1). Therefore, based on morphology, biochemical and 16S rDNA sequence based phylogeny the strain was identified as B. cereus IB131.

$B$. cereus is a gram-positive, facultative anaerobic, rod shaped, endospore-forming bacterium, which occurs ubiquitously in soil (Sarrías et al. 2002, Guinebretiere et al. 2003, Kuta et al. 2009, Tallent et al. 2012). Furthermore, Bacillus produce spores resistant to UV light and heat, which allows them to survive in adverse environmental conditions, and permits easy formulation for commercial purposes (Raaijmakers et al. 2002). In general, Bacillus spp. produces several kinds of antibiotics, including bacillomycin, fengycin, mycosubtilin, and zwittermicin, which are effective in controlling the growth of target pathogens (Pal and McSpadden Gardener 2006). B. cereus UW85 was isolated from a root of a field-grown alfalfa plant from Arlington, WI, and identified for its ability to suppress damping off, a disease caused by Phytophthora megasperma f. sp. medicaginis on alfalfa. This strain was reported to produces two antibiotics (zwittermicin A and kanosamine) that contribute to its ability to suppress certain plant diseases (Emmert and Handelsman 1999, Emmert et al. 2004, Lozano et al. 2016).

\section{APPLICATION OF BIO-CONTROLLING AGENT IN SESAME AND GROUND NUT AGRICULTURAL FIELD}

The results showed that the yield criteria viz., PN, SN and SY were influenced by different treatments $\mathrm{TS} 3 \geq \mathrm{TS} 2>\mathrm{TS} 1$ (Fig. 2). In details, the SY was fond maximum when treated with the experimental strain (TS3), and about 20\% increment in ground nut and $26 \%$ increment in sesame yield was achieved in comparison to positive control (TS2). Similarly, PN was significantly increased in TS2 and TS3 treated field, compared to TS1 (Fig. 2a, b). The difference in seed number ( $\mathrm{SN}$ ) was not significantly distinct in case of ground nut at $\mathrm{p}>0.05$ level (Fig. 2a), however, this difference was significant in case of sesame (Fig. 2b).

The yield parameters directly prove the beneficiary effect of the selected bacterium a

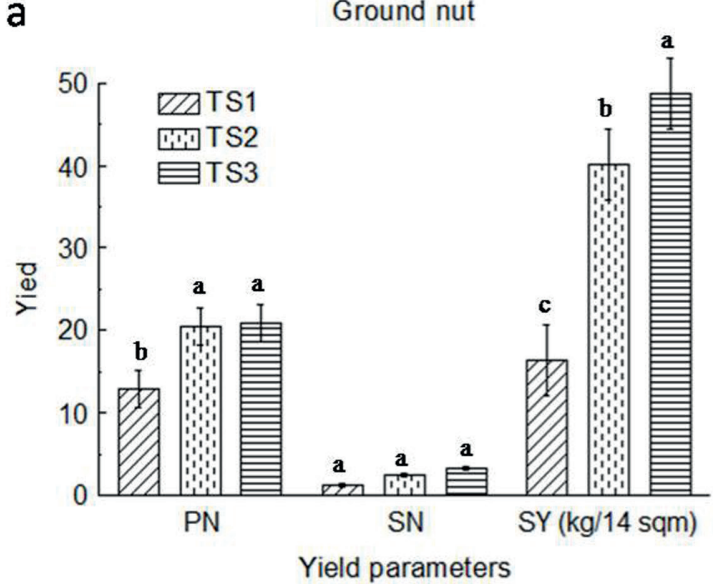

b

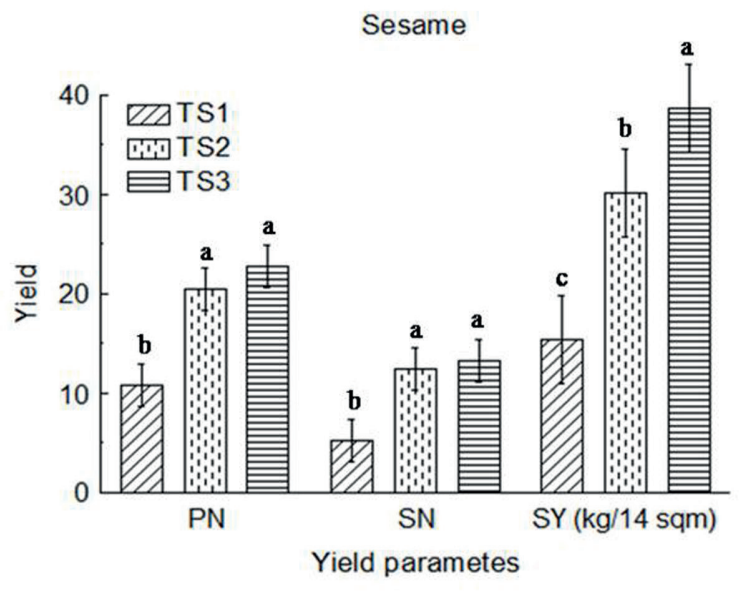

Figure 2 - Use of bio-controlling agent in agricultural field. a: Effect of B. cereus IB311 on ground nut (Arachis hypogaea) production in field trial experiments. b: Effect of B. cereus IB311 on sesame (Sesamum indicum) production in field trial experiments. PN- average pod number per plant, SN- average seed number per pod, SY- seed yield per experimental plot. TS1untreated experimental plots (negative control), TS2- experimental plots treated with $100 \%$ recommended dose of NPK (positive control), TS3- experimental plots treated with B. cereus IB311. 
$B$. cereus IB311. In the present investigation, B. cereus IB311 was found to possess antiphytopathogen activity in laboratory condition and found to enhance yield in the field. Therefore, we may conclude that anti-phytopathogen activity of the strain might be one of the reasons of yield enhancement in the field. Previously, several reports have been published regarding the inhibition of plant pathogens (Makovitzki et al. 2007, Ramzan et al. 2014, Ahemad and Kibret 2014); however, the information regarding the direct application of such bio-controlling agent in agricultural field is scanty.

\section{OPTIMIZATION OF BIOMASS PRODUCTION BY} RSM

In this present investigation, CCD was used and experimental data of 20 runs were summarized in Table II, which indicated the interaction between different variables (glucose, beef extract and inoculum size). Among the three parameters studied in this investigation, the inoculum size was found to be an insignificant variable. According to the results obtained from the analysis of variance, a second degree polynomial model was fitted to this present experiment (Table IV). The $\mathrm{P}$ value for lack of fit $(\mathrm{P}>\mathrm{F})$ is 0.0074 , suggesting that this model adequately fits the data and there is only $0.74 \%$ chance that it is due to noise. The "lack of fit" $F$ value is 6.51 , which indicated an insignificant lack of fit. The model $F$ value of 10.32 and low probability value imply the significant model fit (Table IV). The coefficient of determinant $\left(\mathrm{R}^{2}\right)$ was 0.8902 , which indicated the variability of the model, as well as real relationship between variables. This $\mathrm{R}^{2}$ value explained the variability of the model by $99.9 \%$ and only $0.1 \%$ by chance. The coefficient of variance (C.V.) of the model was $8.24 \%$, which indicated the degree of precision. The adequate precision value was 10.535 , which simply indicated the signal to noise ratio (Table V). According to Cao and Jin (2004), the desired adequate precision value must be greater than 4 for reliability of model. Multiple regression analysis of the experimental data, followed by second degree polynomial equation (3) was found to describe the interaction between glucose, beef extract and inoculum size for $B$. cereus IB311 production.

Biomass $($ dry wt. $)=1.65423+0.23049$ Glucose +3.35353 Beefextract-0.11821 Inoculumsize0.142111 Glucose $\times$ Beefextract +0.13684 Glucose $\times$ Inoculumsize -0.043750 Beefextract $\times$ Inoculum size-0.026320Glucose2-0.60625Beefextract20.11607 Inocumumsize 2

Where, glucose, beef extract and inoculum size are the three variables already mentioned in Table II. The three dimensional surface plots were drawn from the inter-relationship of two variables a

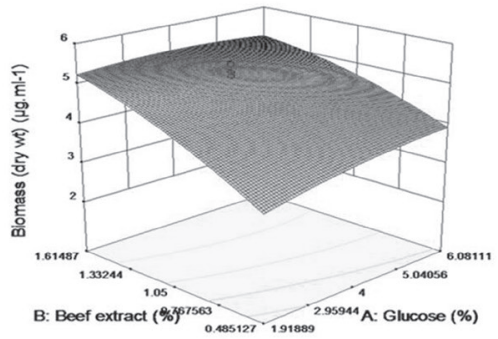

b

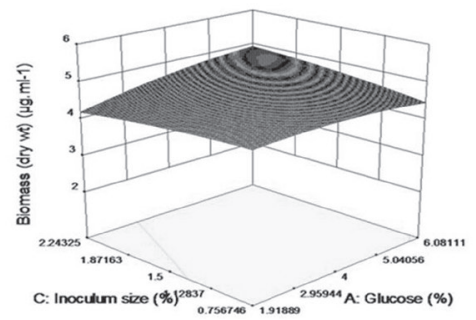

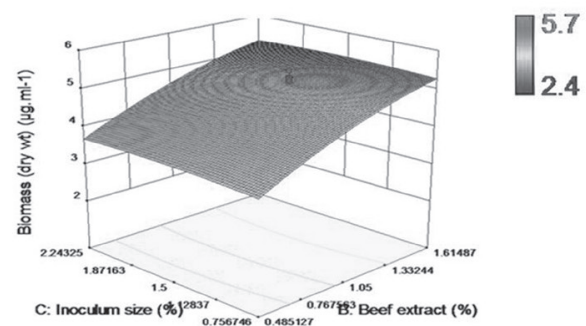

Figure 3 - Response surface graph of $B$. cereus IB311 production in terms of biomass (dry wt.). a: The effect of glucose and beef extract on B. cereus IB311 production. b: The effect of glucose and inoculums sizes on B. cereus IB311 production. c: The effect of beef extract and inoculums size on $B$. cereus IB311 production. 
TABLE IV

ANOVA for quadratic model showing interaction between three variables.

\begin{tabular}{|c|c|c|c|c|c|}
\hline Source & Sum of square & Degree of freedom & Mean square & F value & $\begin{array}{c}\text { P value } \\
(\text { Prob }>\text { F })\end{array}$ \\
\hline Model & 12.05 & 9 & 1.34 & 9.00 & 0.0010 \\
\hline A-Glucose & 0.22 & 1 & 0.22 & 1.47 & 0.2530 \\
\hline B-Beef extract & 10.29 & 1 & 10.29 & 69.24 & $<0.0001$ \\
\hline C-Inoculum size & $5.240 \mathrm{E}-003$ & 1 & $5.240 \mathrm{E}-003$ & 0.035 & 0.8548 \\
\hline $\mathrm{AB}$ & 0.32 & 1 & 0.32 & 2.14 & 0.1741 \\
\hline $\mathrm{AC}$ & 0.13 & 1 & 0.13 & 0.88 & 0.3697 \\
\hline $\mathrm{BC}$ & $1.589 \mathrm{E}-003$ & 1 & $1.589 \mathrm{E}-003$ & 0.011 & 0.9197 \\
\hline $\mathrm{A} 2$ & 0.15 & 1 & 0.15 & 0.98 & 0.3454 \\
\hline $\mathrm{B} 2$ & 1.14 & 1 & 1.14 & 7.69 & 0.0197 \\
\hline $\mathrm{C} 2$ & 0.052 & 1 & 0.052 & 0.35 & 0.5678 \\
\hline Residual & 1.49 & 10 & 0.15 & & \\
\hline Lack of fit & 1.30 & 4 & 0.32 & 10.32 & 0.0074 \\
\hline Pure error & 0.19 & 6 & 0.031 & & \\
\hline Cor total & 13.53 & 19 & & & \\
\hline
\end{tabular}

TABLE V

Statistical information of the model.

\begin{tabular}{ll}
\hline Source & Response \\
\hline R square & 0.8902 \\
Adjusted R square & 0.7913 \\
Coefficient of variation (\%) & 8.24 \\
Standard deviation & 0.39 \\
Adequate precision & 10.535 \\
\hline
\end{tabular}

considering one variable constant. Surface response of the plots indicates the effect of glucose, beef extract and inoculum size on $B$. cereus IB311 production (Fig. 3). In order to determine the optimum conditions of $B$. cereus IB311 production, combined effect of these three variables was also checked. Theoretically, the optimum biomass of B. cereus IB311 $(5.383 \mu \mathrm{g} / \mathrm{mL})$ can be obtained considering glucose $1.985 \%$, beef extract $1.615 \%$ and inoculums size $0.757 \%$. To validate the data, we have conducted an experiment with these possible values. Results obtained were $5.45 \mu \mathrm{g} / \mathrm{ml}$ dry weight produced at glucose $2 \%$, beef extract $1.5 \%$ and inoculums size $0.75 \%$.

Optimization of nutritional (carbon source and nitrogen source) is one of the most important steps to enhance the production in both laboratory experiments, as well as in fermentation industries. Changes in one of these parameters can have a dramatic effect on the yield of cells and the stability of protein product. Many bacterial biocontrolling agents are used in the field directly including Bacillus thuringiensis and Serratia entomophila (Chattopadhyay et al. 2017). Product formulation also requires mass production of BCA (Chattopadhyay et al. 2017). Therefore, in the present investigation, we opt for optimization of mass production of the selected strain. Results of this study are consistent with those of previous studies, where the culture media had a significant influence on production of B. cereus (De Sarrau et al. 2012, Singh et al. 2013). Singh et al. (2013) used response 
surface methodology and artificial neural network to optimize cultural conditions of L-glutaminase production from Bacillus cereus MTCC 1305. The production of L-glutaminase was enhanced by 1.58 -fold after optimization of cultural conditions.

\section{CONCLUSIONS}

This is the first report on use of response surface methodology to improve production of biocontrolling agent like Bacillus cereus. The application of response surface methodology not only resulted in an enhancement in biomass production but also minimized the production cost. Our investigation also has clearly demonstrated that the $B$. cereus IB311 has beneficiary effect in agricultural field. Due to safe, cost effective and positive impact on agricultural field, this bacterial strain will be a good bio-controlling candidate.

\section{ACKNOWLEDGMENTS}

We are thankful to M/S Ajay Biotech India Ltd., Pune - 411 003, Maharastra, India for providing necessary support.

\section{REFERENCES}

AHEMAD M AND KIBRET M. 2014. Mechanisms and applications of plant growth promoting rhizobacteria: Current perspective. J King Saud Univ Sci 26: 1-20.

BULL CT AND KOIKE ST. 2015. Practical benefits of knowing the enemy: modern molecular tools for diagnosing the etiology of bacterial diseases and understanding the taxonomy and diversity of plant-pathogenic bacteria. Ann Rev Phytopathol 53: 157-180.

CAO XZ AND JIN ZY. 2004. Application of response surface methodology in enzymatic reaction using cyclodextrin glycostransferase. J Zhengzhou Inst Technol 1: 016.

CHATTOPADHYAY P, BANERJEE G AND MUKHERJEE

S. 2017. Recent trends of modern bacterial insecticides for pest control practice in integrated crop management system. 3 Biotech 7: 60 .

CHATTOPADHYAY P, KARMAKAR N, CHATTERJEE S AND SEN SK. 2014. Field efficacy of inorganic carrier based formulations of Serratia entomophila AB2 in Sesamum indicum var. Kanak. Afr J Biotechnol 13: 34813488 .
DE SARRAU B, CLAVEL T, CLERTÉ C, CARLIN F AND GINIÈS C. 2012. Influence of anaerobiosis and low temperature on Bacillus cereus growth, metabolism, and membrane properties. Appl Environ Microbiol 78: 1715-1723.

EMMERT EA AND HANDELSMAN J. 1999. Biocontrol of plant disease: a (Gram-) positive perspective. FEMS Microbiol Lett 171: 1-9.

EMMERT EA, KLIMOWICZ AK, THOMAS MG AND HANDELSMAN J. 2004. Genetics of zwittermicin A production by Bacillus cereus. Appl Environ Microbiol 70: 104-113.

G UINEBRETIERE MH, GIRARDIN H, DARGAIGNARATZ C, CARLIN F AND NGUYENTHE C. 2003. Contamination flows of Bacillus cereus and spore-forming aerobic bacteria in a cooked, pasteurized and chilled zucchini puree processing line. Int J Food Microbiol 82: 223-232.

ISLAM M, JEONG YT, LEE YS AND SONG CH. 2012. Isolation and identification of antifungal compounds from Bacillus subtilis C9 inhibiting the growth of plant pathogenic fungi. Mycobiology 40: 59-66.

KRIEG A. 1987. Diseases caused by bacteria and other prokaryotes. Epizootiology of insect diseases. J Wiley \& Sons, Inc., New York, NY, p. 323-355.

KUTA FA, NIMZING L AND ORKA'A PY. 2009. Screening of Bacillus species with potentials of antibiotics production. Appl Med Inform 24: 42-46.

LOZANO GL, HOLT J, RAVEL J, RASKO DA, THOMAS MG AND HANDELSMAN J. 2016. Draft genome sequence of biocontrol agent Bacillus cereus UW85. Genome Announce 4: e00910-16.

MAJEED A, ABBASI MK, HAMEED S, IMRAN A AND RAHIM N. 2015. Isolation and characterization of plant growth-promoting rhizobacteria from wheat rhizosphere and their effect on plant growth promotion. Front Microbiol 6: 198.

MAKOVITZKI A, VITERBO A, BROTMAN Y, CHET I AND SHAI Y. 2007. Inhibition of fungal and bacterial plant pathogens in vitro and in planta with ultrashort cationic Lipopeptides. Appl Environ Microbiol 73: 66296636.

MANSFIELD J ET AL. 2012. Top 10 plant pathogenic bacteria in molecular plant pathology. Mol Plant Pathol 13: 614-629.

NOWELL RW, LAUE BE, SHARP PM AND GREEN S. 2016. Comparative genomics reveals genes significantly associated with woody hosts in the plant pathogen Pseudomonas syringae. Mol Plant Pathol 17: 1409-1424.

O'NEIL RJ. 1997. Ecologically based pest management: New solutions for a new century: Committee on Pest and Pathogen Control Through Management of Biological Control Agents and Enhanced Cycles and Natural Processes, National Research Council. ISBN 030905330 
7. National Academy Press, Washington DC, 144 p.

PAL KK AND MCSPADDEN GARDENER BM. 2006. Biological control of plant pathogens. The Plant Health Instructor 2006. http://dx.doi.org/10.1094/PHIA-20061117-02.

RAAIJMAKERS JM, VLAMI M AND DE SOUZA JT. 2002. Antibiotic production by bacterial biocontrol agents. Antonie van Leeuwenhoek 81: 537-547.

RAMZAN N, NOREEN N AND SHAHZAD S. 2014. Inhibition of in vitro growth of soil-borne pathogens by compost-inhabiting indigenous bacteria and fungai. Pak J Bot 46: 1093-1099.

SARRÍAS JA, VALERO M AND SALMERO’N MC. 2002. Enumeration, isolation and characterization of Bacillus cereus strains from Spanish raw rice. Food Microbiol 19: 589-595.

SERRANO MC, RAMIREZ M, MORILLA D, VALVERDE A, CHÁVEZ M, ESPINEL-INGROFF A, CLARO R, FERNÁNDEZ A, ALMEIDA C AND MARTÍN-MAZUELOS E. 2004. A comparative study of the disc diffusion method with the broth microdilution and Etest methods for voriconazole susceptibility testing of Aspergillus spp. J Antimicrob Chemother 53: 739-742. SINGH P, SHERA SS, BANIK J AND BANIK RM. 2013. Optimization of cultural conditions using response surface methodology versus artificial neural network and modeling of L-glutaminase production by Bacillus cereus MTCC 1305. Bioresour Technol 137: 261-269.

SUBRAMONI S, NATHOO N, KLIMOV E AND YUAN ZC. 2015. Agrobacterium tumefaciens responses to plantderived signaling molecules. Front Plant Sci 5: 322.

TALLENT SM, KOTEWICZ KM, STRAIN EA AND BENNETT RW.2012. Efficient isolation and identification of Bacillus cereus group. J AOAC Int 95: 446-451.

TAMURA K, STECHER G, PETERSON D, FILIPSKI A AND KUMAR S. 2013. MEGA6: molecular evolutionary genetics analysis version 6.0.Mol Biol Evol 30: 2725-2729.

TYLER VE, BRADY LR AND ROBBERS JE. 1988. Pharmacognosy, $9^{\text {th }}$ ed., Lea and Fbiger, Philadelphia, p. 312-318.

WONG HC, CHANG MH AND FAN JY. 1988. Incidence and characterization of Bacillus cereus isolates contaminating dairy products. Appl Environ Microbiol 54: 699-702. 